Bangladesh J. Plant Taxon. 25(2): 215-226, 2018 (December)

(C) 2018 Bangladesh Association of Plant Taxonomists

\title{
MORPHOLOGICAL, ANATOMICAL AND CYTOLOGICAL INVESTIGATIONS ON THREE TAXA OF CENTAUREA L. (ASTERACEAE) FROM TURKEY
}

\author{
Neslihan Taşar, Gülden DoĞan ${ }^{1}$, Yaşar Kiran $^{1}$, M. Oliur Rahman ${ }^{2}$ \\ AND UĞUR ÇAKILCIOĞLU ${ }^{3}$ \\ Munzur University, Tunceli Vocational School, Department of Organic Agriculture, \\ Tunceli, Turkey
}

Keywords: Centaurea; Anatomy; Cytology; Taxonomy; Asteraceae; Turkey.

\begin{abstract}
Morphological, anatomical and cytological features of three Turkish taxa of Centaurea L., viz. C. polypodiifolia Boiss. var. polypodiifolia, C. urvillei DC. subsp. urvillei and $C$. urvillei subsp. armata Wagenitz were investigated. Stem anatomy revealed the presence of a thick cuticle layer outside the stem, and epidermis with dense hairs was observed in the lower part. Investigation on leaf anatomy showed that different types of hairs on the outside of the leaf were very intense. Palisade parenchyma was observed below the upper and lower epidermis. In Centaurea polypodiifolia var. polypodiifolia, chromosome number was found to be $2 \mathrm{n}=16$, while in $C$. urvillei subsp. urvillei and $C$. urvillei subsp. armata $2 \mathrm{n}=20$. Total karyotype length of $C$. polypodiifolia var. polypodiifolia, C. urvillei subsp. urvillei and C. urvillei subsp. armata was $22.9 \mu \mathrm{m}$, $37.84 \mu \mathrm{m}$ and $40.01 \mu \mathrm{m}$, respectively. Among the investigated taxa the karyotype asymmetry index was found lowest in C. urvillei subsp. armata. Satellite was detected in C. urvillei subsp. urvillei and subsp. armata, while it was absent in C. polypodiifolia Boiss. var. polypodiifolia.
\end{abstract}

\section{Introduction}

Centaurea L. (Asteraceae) consists of about 700 species and distributed in the Mediterranean region and the Near East with a few species reaching northern Eurasia, north and east Africa, North America, and Australia (Bancheva et al., 2014; Behçet et al., 2017). Turkey is one of the main centers of this genus, particularly the Southwest and East of the country (Wagenitz, 1986), and regarded as the third largest genus in Turkey (Davis, 1975). In Turkey, Centaurea is represented by 194 species, of which 118 are endemic (Guner et al., 2012). The systematics of the genus Centaurea is problematic, and the sectional classification of Centaurea relies heavily on the morphology of the appendage of phillary and achenes (Garcia-Jacas et al., 2001). The taxonomic coplexity of Centaurea, especially in the Near East, has stirred much research (Duran and Duman, 2002; Türkoglu et al., 2003; Yüzbaşıŏlu et al., 2015). The status of species and infraspecific taxa included in Centaurea has been revised in several taxonomic treatments (Rahiminejad et al., 2010; Ranjbar and Negaresh, 2013; Negaresh and Rahiminejad, 2014). In the recent past, several authors concentrated on morphological studies of Centaurea alongside describing new species from Turkey (Kose et al., 2010; Hayta et al., 2016; Behçet et al., 2017).

Anatomical and cytological characters play pivotal role in plant systematics, and quite often offer tools for species delimitation. Stem and leaf anatomy provide many characters which have

${ }^{1}$ Firat University, Science Faculty, Biology Department, Elazı ̆̆, Turkey.

${ }^{3}$ Department of Botany, University of Dhaka, Dhaka 1000, Bangladesh.

${ }^{3}$ Munzur University, Pertek Sakine Genç Vocational School, Tunceli, Turkey. Correspending author.

Email: ucakilcioglu@yahoo.com 
already been proven to be of importance in classification (Lu et al., 2008), and have been widely used in taxonomic treatments and systematic studies (Noman et al., 2014). Though some taxa of Centaurea were investigated based on anatomical (Ozcan, 2013; Uysal et al., 2016) and cytological (Martin et al., 2006; Uysal et al., 2009) characters, many taxa of this genus occurring in Turkey remain unexplored using these important tools. Since Centaurea is taxonomically a complicated genus as it contains many taxa that show a great degree of morphological variations, anatomical and cytological data should be involved to resolve taxonomic limits. Therefore, the present study aimed at exploring the anatomical and cytological features of three Centaurea taxa from Turkey and to enrich the knowledge of these features for better understanding of systemaics of Centaurea.

\section{Materials and Methods}

Plant materials

Plant materials were collected from natural habitats from 2011 to 2012. The voucher specimens have been deposited at the Firat University Herbarium (FUH). The taxonomic identifications of the taxa were confirmed following Davis (1975). The list of the taxa investigated in this study along with their localities and vouchers are provided in Table 1.

Table 1. List of the investigated taxa with their localities and voucher specimens.

\begin{tabular}{lll}
\hline Taxa & Locality & Vouchers \\
\hline Centaurea polypodiifolia Boiss. & B7/Elazı̆̆ Çemişgezek, Danbüken, Avşan & Tasar, 1005 \\
var. polypodiifolia & Köyü, 1090 m. 16.07.2012 & \\
C. urvillei DC. subsp. urvillei & B7/Elazı̆ğ Harput, Anguza Baba, & Tasar, 1008 \\
& Kayalık alan, 1400 m. 13.06.2011 & \\
C. urvillei subsp. armata & B7/ Elazı̆g, Baskil, Yukarı Kuluşağ Köyü, & Tasar, 1009 \\
Wagenitz & Kayalık alan, 1400 m. 13.06.2011 & \\
\hline
\end{tabular}

Anatomical investigation

Cross sections of stem, root, leaf and surface sections of leaf of three taxa of Centaurea were made after fixing in 70\% ethanol (Yakar-Tan, 1982). The sections were observed under light microscope Olympus BX51 and photographed with Olympus Camedia C-4000 digital camera.

\section{Cytological study}

The cytological studies were conducted on root tips meristematic cells. The seeds were germinated on moist filter paper in Petri dishes at $25^{\circ} \mathrm{C}$. The actively growing root tips were pretreated with aqueous colchicine $(0.05 \%)$ for $3-3.5 \mathrm{~h}$ at room temperature. Afterwards, the root tips were fixed with Carnoy (1:3 glacial acetic acid-absolute ethanol) for at least $24 \mathrm{~h}$ at $4^{\circ} \mathrm{C}$, hydrolysed in $1 \mathrm{~N} \mathrm{HCl}$ at $60^{\circ} \mathrm{C}$ for $15 \mathrm{~min}$, then rinsed in tap water for 3-5 min. Finally, they were stained in Feulgen for $1 \mathrm{~h}$ and mounted in $45 \%$ acetic acid. Digital microphotographs from at least 5 well-spread metaphase plates were taken using an Olympus BX51 microscope, and were recorded with an Olympus Camedia C-4000 digital camera. Diploid chromosome number (2n), ploidy level, karyotype formula, chromosome length range and total karyotype length (TKL) were determined. Chromosomes were classified according to nomenclature given by Levan et al. (1964). The intrachromosomal asymmetry index (A1) and the interchromosomal asymmetry index (A2) followed Romero-Zarco (1986), while the karyotype symmetry nomenclature followed Stebbins (1971). For calculating coefficient of variation of chromosome length $\left(\mathrm{CV}_{\mathrm{CL}}\right)$, coefficient of variation of the centromeric index $\left(\mathrm{CV}_{\mathrm{CI}}\right)$ and asymmetry index (AI) Paszko (2006) was tailed. 


\section{Results and Discussion}

\section{Morphological characteristics}

Centaurea polypodiifolia Boiss., Diagn. Pl. Orient. Ser. 1, 6: 126 (1846), var. polypodiifolia. $C$. euphratica Boiss., Diagn. Pl. Orient. Ser. 1, 6: 125 (1845). Microlophus polypodiifolius (Boiss.) Agadshanov, Fl. Azerb. 8: 443 (1961).

(Fig. 1A-B).

Biennial or perennial, 33-44 cm long, with numerous branches and thickened taproot. Root 16-23 cm long. Stem, branches and lower leaves with crisp articulate hairs, other leaves almost glabrescent. Lower leaves $120-180 \times 50-80 \mathrm{~mm}$, median leaves 50-90×10-18 mm. Capitula corymbosely arranged, $2.5-3.5 \mathrm{~cm}$ long. Flowers yellow. Appendage very small $(0.5-2.5 \mathrm{~mm})$ and easily deciduous, a simple spinule or with 1-2 pairs of minute teeth. Involucre $16-20 \times 10-13 \mathrm{~mm}$, rarely broader, upper leaves narrowly lanceolate, not concealing involucre. Outer phyllaries 8-12 x 5-7 mm, median phyllaries $10-14 \times 4-7 \mathrm{~mm}$, inner phyllaries $15-18 \times 2-4 \mathrm{~mm}$. Achenes $4-5 \mathrm{~mm}$, pappus $5-8 \mathrm{~mm}$ long.

Flowering: June to August.

Habitat: Rocky slopes, steppe, fallow fields, at 800-2500 m above the sea level.

Centaurea urvillei DC., Prodr. 6: 592 (1838), subsp. urvillei. Aegialophila longispina Cand. in Bull. Soc. Bot. Fr. 44: 146 (1897). C. urvillei DC. var. leptacantha Bornm. in Beih. Bot. Centr. 38(2): 464 (1921). C. chiosicola Beauv. \& Topali in Bull. Soc. Bot. Geneve Ser. 2, 26: 156 (1936).

(Fig. 1C-D).

Short-lived perennial, $12-28 \mathrm{~cm}$ tall. Root 3-5 cm long. Stem simple or branched from near base, very short or elongate, mostly rather slender. Lower leaves $90-12 \times 30-50 \mathrm{~mm}$, median leaves 150-210 x 23-42 mm, slightly arachnoid to distinctly tomentose, lyrate with triangular, rhombic or oblong-ovate terminal segments, few to numerous lanceolate, lateral segments of leaves entire or dentate. Capitula 1-4, c. 5-7 cm long. Flowers rose-purple or whitish. Appandages (excluding cilia) $2-4(-5) \mathrm{mm}$ broad at the base, rarely more than $20 \mathrm{~mm}$ long. Involucre $30-40 \times 17-38 \mathrm{~mm}$, ovoid to globose. Outer phyllaries 7-12×5-9 mm, median phyllaries 13-15×5-7 mm, inner phyllaries 15-22 × 5-7 mm. Achenes 4-6 mm long, pappus 7-12 $\mathrm{mm}$ long.

Flowering: June to July.

Habitat: Rocky slopes, macchie, open Pinus forests, at $2000 \mathrm{~m}$ above sea level.

Centaurea urvillei DC., Prodr. 6: 592 (1838), subsp. armata Wagenitz., Willdenowia 6(3): 491 (1972). C. urvillei DC. var. platyacantha Bornm. in Beih. Centr. 38(2): 464 (1921) (Fig. 1E-F).

Short-lived perennial or biennial, $11-20 \mathrm{~cm}$ long. Root 4-10 $\mathrm{cm}$ long. Stem simple or branched from near the base, short or elongated, stout. Lower leaves 90-120 $\times 25-30 \mathrm{~mm}$, median leaves $110-160 \times 30-50 \mathrm{~mm}$, slightly arachnoid to distinctly tomentose, lyrate with triangular, rhombic or oblong-ovate terminal segments, few to numerous lanceolate, oblong or lyrate, interspersed with small lobes. Capitulum $5.0-5.5 \mathrm{~cm}$ long. Flowers rose-purple or whitish. Appandages 4-7 mm broad at the base, with 8-12 cilia on each side. Involucre 30-35×30-40 mm, ovoid to globose. Outer phyllaries $15-24 \times 8-10 \mathrm{~mm}$, median phyllaries $15-18 \times 5-10 \mathrm{~mm}$, inner phyllaries 20-25×6-10 mm. Achenes 4-6 mm long, pappus 6-13 mm long.

Flowering: June to August.

Habitat: Dry stony slopes, scree, rocks, at 50-2800 m above sea level.

Notes: The present morphological investigation deals with in-depth study including the several quantitative characters of three taxa of Centaurea, viz, size of root, lower and median leaves, outher, median and inner phyllaries and capitulum, where these characters are missing in the Flora of Turkey (Davis, 1975). 

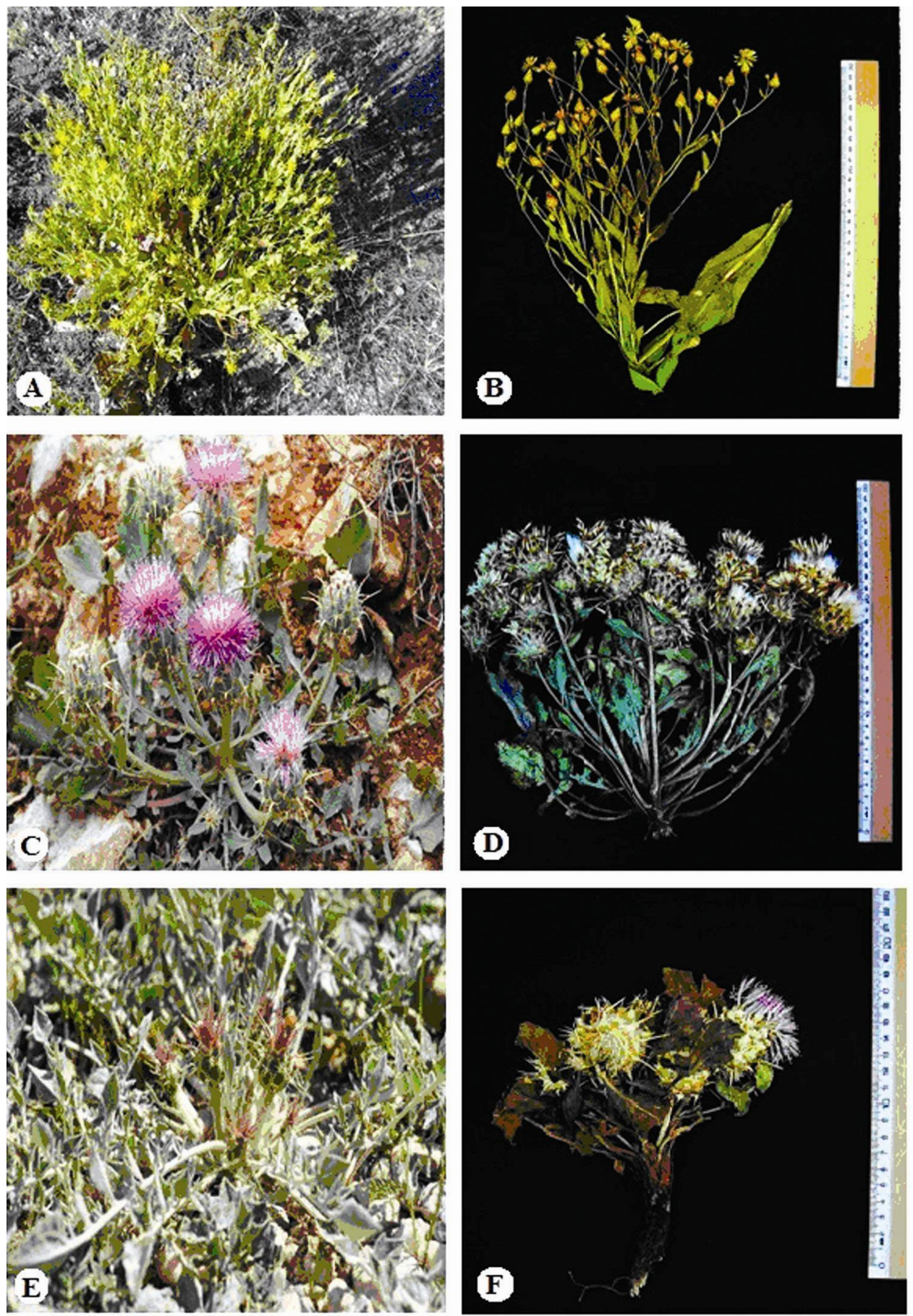

Fig. 1. A-B: Centaurea polypodiifolia var. polypodiifolia; C-D: C. urvillei subsp. urvillei, E-F: C. urvillei subsp. armata; A,C,E: Habitat, B,D,F: Herbarium specimens. 


\section{Anatomical characters}

\section{Root anatomy}

The outer layer contains a periderm in the form of an epidermis (protective tissue). The crushed epidermis is found below the peridermis. Under the epidermis is a cortex layer consisting of small, ovoid, thick-walled parenchyma cells. Sclerenchymatous bundles are partially embedded in the cortex layer. Under the cortex, there is cambium trapped in a narrow area. Next to the cortex there are well developed vascular bundles. Although the number of phloem cells is less, xylem cells occupy a broader space. The xylem expanded to cover its own pith region (Fig. 2).

\section{Stem anatomy}

Stem anatomy revealed the presence of a thick cuticle layer outside the stem, and in the lower part of it, epidermis with dense hairs was observed. Collenchyma and chlorenchyma occurred in alternating segments below epidermis. There are sclerenchymatous bundles between chlorenchyma and collenchyma. Scleranchyma cells are in the order of 4-5, and there are intercellular spaces between these cells. Under this layer, phloem and xylem are present, respectively. It has been observed that the vascular bundles under the collenchymatic tissue are larger. The vascular bundles in the stem of studied taxa are arranged in two rings and the type of vascular bundles is bicollateral. The cambium is seen as crushed. The phloem in the inner side of xylem is less visible. The collenchyma tissue was generally located very close to the epidermis with 3-4 rows in $C$. urvillei subsp. urvillei and C. urvillei subsp. armata and 4-6 rows in C. poypodiifolia var. polypodiifolia. In addition, a chlorenchymatous tissue below the epidermis was observed in the stem cortex with 3-4 rows in C. urvillei subsp. urvillei and $C$. urvillei subsp. armata and 4-5 rows in C. poypodiifolia var. polypodiifolia (Fig. 2).

\section{Leaf anatomy}

Investigation on leaf anatomy showed different types of hairs on the outside of the leaf that were very intense. On the outer side, there is a cuticular layer framing the epidermis. Under the upper and lower epidermis, there is palisade parenchyma. Because the palisade parenchyma is present on both sides, it can be concluded that the leaf type is isolateral (equifacial). Between the two palisade parenchyma, there is an irregularly arranged spongy parenchyma which occupies less area. All three taxa have equifacial leaves. In C. polypodiifolia var. polypodiifolia, mesophyll tissue consists of 2-3 layers of palisade and 2-3 layers of spongy parenchymatous cells, whereas in C. urvillei subsp. urvillei and C. urvillei subsp. armata it is composed of 3 layers of palisade parenchymatous cells and 2 layers of spongy parenchymatous cells (Fig. 3). In surface section, stoma cells were found as amaryllis type. Stomata are surrounded by usually 3 , and rarely 4 neighboring cells. The type of stomata is anisocytic (Fig. 3).

\section{Cytological characters}

Chromosome numbers and detailed chromosome morphology of three Centaurea taxa are reported in this study. In Centaurea polypodiifolia Boiss. var. polypodiifolia, the chromosome number was found to be $2 n=16$ and the basic chromosome number of $x=8$. The shortest chromosome length is $1.92 \mu \mathrm{m}$, while the longest is $4.66 \mu \mathrm{m}$, and haploid chromosome length is $22.9 \mu \mathrm{m}$. The karyotype formula of this taxon is $1 \mathrm{M}+5 \mathrm{~m}+2 \mathrm{sm}$ (Table 2).

In $C$. urvillei subsp. urvillei, chromosome number $2 \mathrm{n}=20$ and the basic chromosome number of $\mathrm{x}=10$ is reported. The shortest chromosome length is $2.80 \mu \mathrm{m}$, the longest is $5.28 \mu \mathrm{m}$ and haploid chromosome length is $37.84 \mu \mathrm{m}$. The karyotype formula of this taxon is $2 \mathrm{M}+5 \mathrm{~m}+3 \mathrm{sm}$ (Table 2). Satellite was detected on the short arm of chromosome 5 in this taxon. The chromosome number of $C$. urville $i$ subsp. armata is $2 \mathrm{n}=20$, where the basic chromosome number of $\mathrm{x}=10$. The 
shortest chromosome length is $3.05 \mu \mathrm{m}$, the longest $4.74 \mu \mathrm{m}$ and haploid chromosome length is $41.01 \mu \mathrm{m}$. The karyotype formula of this taxon is $2 \mathrm{M}+5 \mathrm{~m}+3 \mathrm{sm}$ (Table 2). Satellite was detected on the short arm of chromosome 3. Other karyotype parameters and asymmetries are given in Table 3. Somatic metaphase chromosomes and idiograms of all three taxa of Centaurea are presented in Figures 4 and 5.
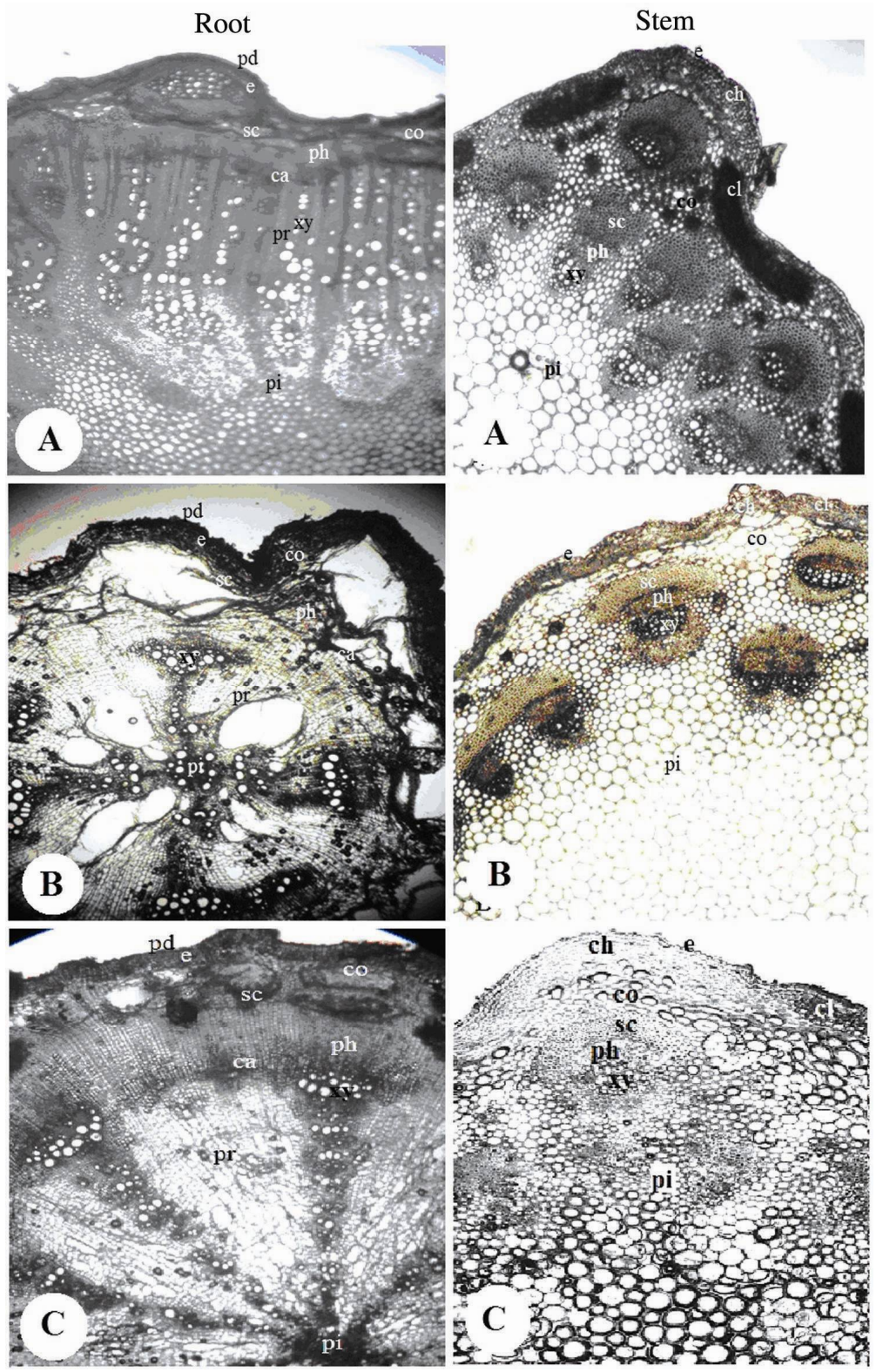

Fig. 2. Cross-sections of stems and roots. A. Centaurea polypodiifolia var. polypodiifolia; B. C. urvillei subsp. urvillei; C. C. urvillei subsp armata. (pd=periderm, e=epidermis, co=cortex, sc=sclerenchyma, $\mathrm{ph}=$ phloem, ca=cambium, $\mathrm{xy}=\mathrm{xylem}, \mathrm{pr}=$ pith ray, $\mathrm{pi}=\mathrm{pith}, \mathrm{ch}=$ collenchyma, $\mathrm{cl}=$ chlorenchyma $)$. 

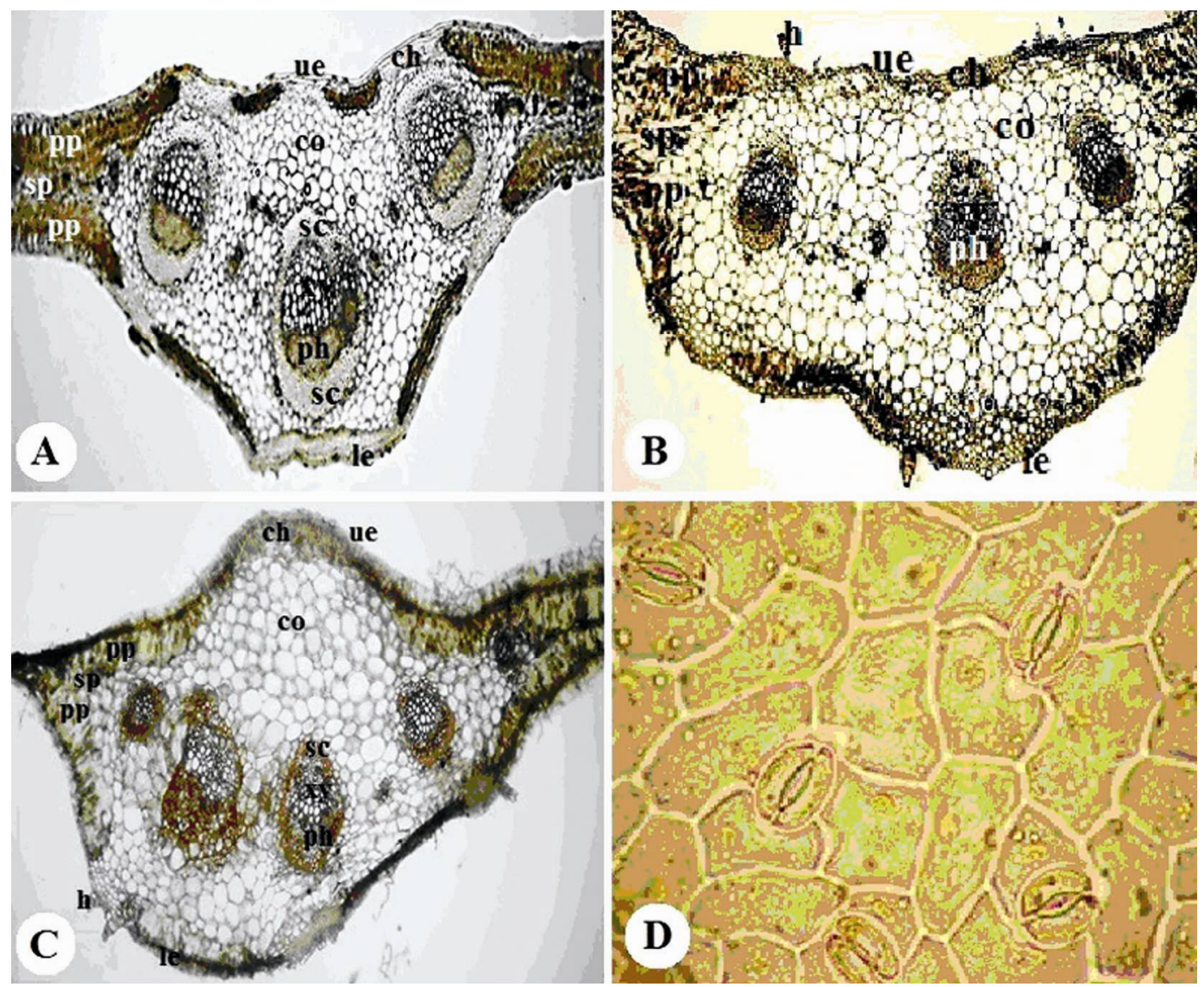

Fig. 3. Cross-sections of leaves of three Centaurea taxa. A. C. polypodiifolia var. polypodiifolia; B. $C$. urvillei subsp. urvillei; C. C. urvillei subsp. armata; D. Surface section of leaf of C. polypodiifolia var. polypodiifolia (other two taxa similar) ( $\mathrm{h}=$ hair, ue=upper epidermis, $\mathrm{ch}=$ collenchyma, $\mathrm{co}=\mathrm{cortex}$, $\mathrm{sc}=$ sclerenchyma, $\mathrm{ph}=$ phloem, $\mathrm{xy}=\mathrm{xylem}, \mathrm{pp}=$ palisade parenchyma, $\mathrm{sp}=$ spongy parenchyma, le=lower epidermis).
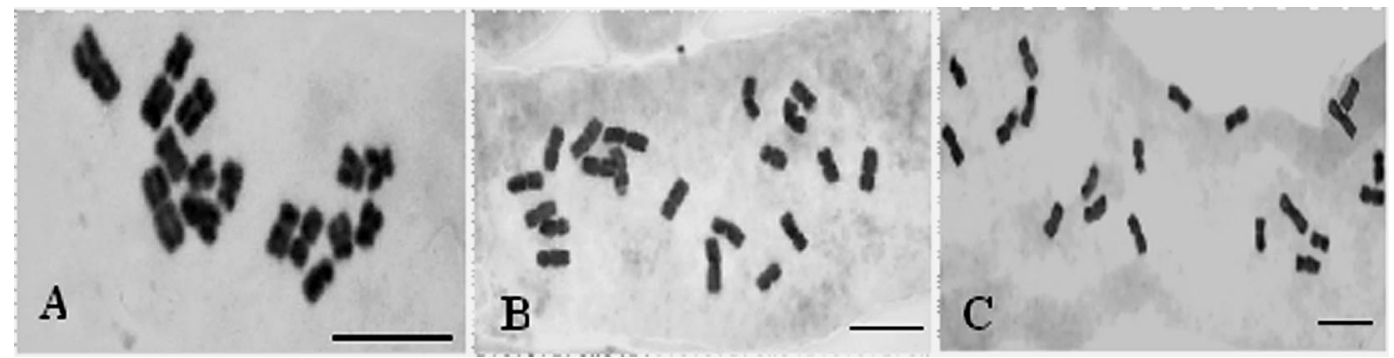

Fig. 4. Somatic metaphase chromosomes of three Centaurea taxa. A. C. polypodiifolia var. polypodiifolia $(2 \mathrm{n}=16) ;$ B. C. urvillei subsp. urvillei $(2 \mathrm{n}=20)$; C. C. urvillei subsp. armata $(2 \mathrm{n}=20)$ (Scale bars: 10 $\mu \mathrm{m})$. 
Table 2. Karyological features of three taxa of Centaurea studied.

\begin{tabular}{|c|c|c|c|}
\hline Cytological characters & $\begin{array}{l}\text { C. polypodiifolia } \\
\text { var. polypodiifolia }\end{array}$ & $\begin{array}{l}\text { C. urvillei } \\
\text { subsp. urvillei }\end{array}$ & $\begin{array}{l}\text { C. urvillei } \\
\text { subsp. armata }\end{array}$ \\
\hline Chromosome number $(2 n)$ & 16 & 20 & 20 \\
\hline Ploidy level & $2 \mathrm{x}$ & $2 \mathrm{x}$ & $2 \mathrm{x}$ \\
\hline Karyotype formule & $1 \mathrm{M}+5 \mathrm{~m}+2 \mathrm{sm}$ & $2 \mathrm{M}+5 \mathrm{~m}+3 \mathrm{sm}$ & $2 \mathrm{M}+5 \mathrm{~m}+3 \mathrm{sm}$ \\
\hline Chromosome length $(\mu \mathrm{m})$ & $1.92-4.66$ & $2.80-5.28$ & $4.74-3.05$ \\
\hline Total karyotype length (TKL) $(\mu \mathrm{m})$ & 22.9 & 37.84 & 41.01 \\
\hline Intrachromosomal asymmetry index $\left(\mathrm{A}_{1}\right)$ & 0.29 & 0,31 & 0.27 \\
\hline Interchromosomal asymmetry index $\left(\mathrm{A}_{2}\right)$ & 0.32 & 0.21 & 0.14 \\
\hline $\begin{array}{l}\text { Karyotype symmetry nomenclature } \\
\text { followed Stebbins (SC) }\end{array}$ & $3 \mathrm{~B}$ & $3 \mathrm{~A}$ & $3 \mathrm{~A}$ \\
\hline $\begin{array}{l}\text { Coefficient of variation of chromosome } \\
\text { length }\left(\mathrm{CV}_{\mathrm{CL}}\right)\end{array}$ & 32.75 & 21.70 & 14.36 \\
\hline $\begin{array}{l}\text { Coefficient of variation of centromeric } \\
\text { index }\left(\mathrm{CV}_{\mathrm{CI}}\right)\end{array}$ & 15.02 & 22.57 & 19.80 \\
\hline Karyotype asymmetry index (AI) & 4.92 & 4.89 & 2.84 \\
\hline
\end{tabular}
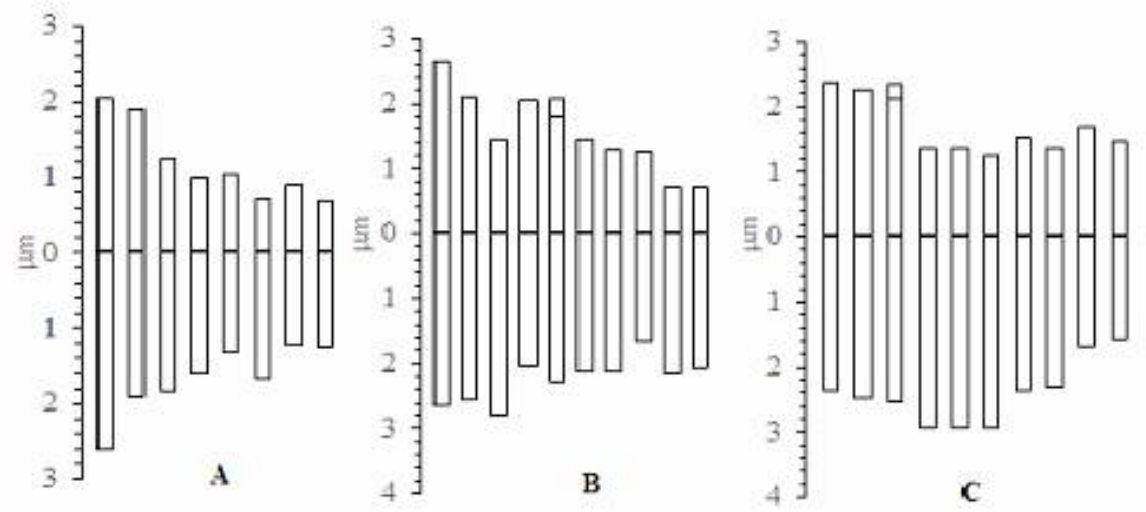

Fig. 5. Idiogram of three Centaurea taxa. A. C. polypodiifolia var. polypodiifolia; B. C. urvillei subsp. urvillei, C. C. urvillei subsp. armata.

The present study was carried out in order to provide useful and additional morphological, anatomical and cytological data for three Centaurea taxa of Turkey, namely $C$. polypodiifolia var. polypodiifolia, C. urvillei subsp. urvillei and C. urvillei subsp. armata. Several attempts have been made to subdivide the genus Centaurea (s.l.) comprising about 300 problematic species (GarciaJacas et al., 2006). Wagenitz (1975) placed these taxa in the two distinct sections of the genus Centaurea, viz. section Acrocentron (C. urvillei subsp. urvillei, C. urvillei subsp. armata) and section Microlopus (C. polypodiifolia var. polypodiifolia) in the Flora of Turkey. Centaurea polypodiifolia Boiss. is one of the six species included in the section Microlophus (Cass.) DC., and is divided into three varieties based on length of appendages and width of involucre. The appandages of $C$. polypodiifolia var. polypodiifolia are very small and easily decidous. The type has narrow upper leaves but larger involucres than most of the other material of this variety and approaches var. szovitsiana in this respect. The appandages of C. polypodiifolia var. pseudobehen 
are very variable and the upper leaves are narrowly lanceolate. The following gathering is almost intermediate between var. polypodiifolia and var. pseudobehen (Davis, 1975).

Centaurea urvillei DC. is one of the seventeen species included in the section Acrocentron (Cass.) DC. and is a very polymorphic species with five distinct subspecies, connected by transitional forms although the extrems (subsp. urvillei and subsp. hayekiana) look very different and could easily be placed at species rank. The geographical differentiation is only partial, especially where the areas of subsp. urvillei and subsp. armata overlap. C. urvillei is endemic to Turkey and closely related to C. lydia and C. raphanina sensu lato (Davis, 1975). C. urvillei subsp. urvillei shows considerable variation in the length of the appendages (spines) and appendages have been found shortest in some samples collected from Sout-western Anatolia of Turkey.

Wagenitz (1975) explained morphological characters in the genus Centaurea, and Metcalfe and Chalk (1979) provided information on anatomical characteristics of the family Asteraceae. In addition to some morphological and anatomical investigations, studies on palynology, phytogeographic distribution and ecology of some Centaurea s.l. species in Turkey were presented (Ozler et al., 2009). However, no detailed morphological and anatomical studies of the investigated taxa are available so far.

In the present study we investigated root, stem and leaf anatomy of $C$. polypodiifolia var. polypodiifolia, C. urvillei subsp. urvillei and C. urvillei subsp. armata. The general root, stem and leaf structure are almost similar in all examined taxa, but a few differences were determined as shown in Figures 2 and 3. The anatomical characters of all studied taxa have been presented here for the first time. In root of all examined taxa, the crushed epidermis is found below the peridermis. Although the number of phloem cells is less, xylem cells occupy a broader space. The xylem expanded to cover its own pith region.

The collenchyma tissue was generally located very close to the epidermis with 3-4 rows in $C$. urvillei subsp. urvillei and subsp. armata and 4-6 rows in C. poypodiifolia var. polypodiifolia. It is well established that the position and the average number of row in collenchyma tissue is important for comparative anatomical studies in plants (Lersten and Curtis, 1997; Makbul et al., 2008). Additionally, a chlorenchymatous tissue below the epidermis was observed in the stem cortex with 3-4 rows in C. urvillei subsp. urvillei and subsp. armata and 4-5 rows in $C$. poypodiifolia var. polypodiifolia. This tissue was reported in the genus Centaurea in some earlier studies (Uysal et al., 2005; Celik et al., 2005, 2008; Kaya et al., 2010). The vascular bundles in stem of Centaurea are generally arranged in 2 rings. Our investigated taxa revealed 2 rings, however, they are sometimes arranged in 1 ring in some taxa of Centaurea. Celik et al. (2005, 2008) and Kaya et al. (2010) reported that vascular bundles are scattered in a circular manner in a single ring in the stem of some Centaurea species.

Leaf anatomical properties are used as significant distinctive characters in plant taxonomy (Uysal et al., 2005; Kaya et al., 2010). In cross-sections of leaves we found that vascular bundle was capped by sclerenchymatic fibres at both sides in all the examined taxa (Fig. 3). However, the sclerenchymatic fibres were more prominent in C. polypodifolia var. polypodifolia. All studied taxa have equifacial leaves, with a mesophyll tissue that consists of 2-3 layers of palisade and 2-3 layers of spongy parenchymatic cells of $C$. polypodiifolia var. polypodiifolia, 3 layers of palisade parenchymatic cells and 2 layers of spongy parenchymatic cells in $C$. urvillei subsp. urvillei and C. urvillei subsp. armata, respectively.

The importance of karyomorphology in Centaurea has long been realized (Garcia-Jacas and Susanna, 1992). In the genus Centaurea in Turkey the somatic chromosome number varies from 2n=16 to 66 (Wagenitz, 1975; Martin et al., 2006; Inceer et al., 2007). The basic chromosome 
number of Centaurea species varies from $x=7$ to 16 and four ploidy levels $(2 x, 3 x, 4 x, 6 x)$ have been determined (Gomurgen et al., 2010; Meric et al., 2010; Kocyigit and Bona, 2013). The cromosome number of $C$. polypodiifolia var. polypodiifolia in the present study was found to be $2 \mathrm{n}=2 \mathrm{x}=16$, and this finding was found consistent with Ghaffari and Shahraki (2001). In C. urvillei subsp. urvillei and subsp armmata $2 \mathrm{n}=2 \mathrm{x}=20$ were found and our results were supported by previous studies (Gardou and Tchehrehgosha, 1975; Garcia-Jacas et al., 1997), although different chromosomal counts for $C$. urvillei subsp. urvillei $(2 \mathrm{n}=40)$ have also been made (Martin et al., 2009). In this study we found anatomical and cytological characters as useful in the taxonomy of three Centaurea taxa in Turkey. Investigation of anatomical features were first of its nature among the studied taxa. The findings of the present study would be useful for contributing to systematics of this genus Centaurea and to infer interspecific relationships based on anatomical and karyological characters.

\section{Acknowledgements}

The financial support from the Scientific Investigation Project Coordinator of Firat University (Project number: FF.12.02) is gratefully acknowledged.

\section{References}

Bancheva, S., Kaya, Z. and Binzet, R. 2014. Morphological, cytological and palynological features of three closely related Centaurea species (Asteraceae) from Turkey. Mod. Phytomorphol 5: 79-84.

Behçet, L., Ilçim. A. and Yapar, Y. 2017. Centaurea bingoelensis (Asteraceae), a new species from Turkey. Turk. J. Bot. 41: 180-188.

Celik, S., Uysal, T., Menemen, Y. and Karabacak, E. 2005. Morphology, anatomy, ecology, pollen and achene structure of Centaurea consanguinea DC. (Sect. Acrolophus) in Turkey. Int. J. Bot. 1: 85-89.

Celik, S., Uysal, T. and Menemen, Y. 2008. Morphology, anatomy, ecology and palynology of two Centaurea species from Turkey. Bangladesh J. Bot. 37: 67-74.

Davis, P.H. (Ed.). 1975. Flora of Turkey and the East Aegean Islands. Vol. 5. Edinburgh University Press, UK.

Duran, A. and Duman, H. 2002. Two new species of Centaurea (Asteraceae) from Turkey. Ann. Bot. Fenn. 39: $43-48$.

Garcia-Jacas, N. and Susanna, A. 1992. Karyological notes on Centaurea sect. Acrocentron. Plant Syst. Evol. 179(1): 1-18.

Garcia-Jacas, N., Susanna, A., Ilarslan, R. and Ilarslan, H. 1997. New chromosome counts in the subtribe Centaureinae (Asteraceae, Cardueae) from West Asia. Bot. J. Linn. Soc. 125: 343-349.

Garcia-Jacas, N., Susanna, A., Garnatje, T. and Vilatersana, R. 2001. Generic delimitation and phylogeny of the subtribe Centaureinae (Asteraceae): a combined nuclear and chloroplast DNA analysis. Ann. Bot. 87: 503-515.

Garcia-Jacas, N., Uysal, T., Romashchenko, K., Suarez-Santiago, V.N., Ertugrul, K. and Susanna, A. 2006. Centaurea Revisited: A molecular survey of the Jacea Group. Ann. Bot. 98: 741-753.

Gardou, C. and Tchehrehgocha, I. 1975. IOPB chromosome number reports XLIX. In: Love, A. (Ed). Taxon 24: 501-516.

Ghaffari, S.M. and Shahraki, M.A. 2001. Some chromosome counts and meiotic behavior in Centaurea species from Iran. Iranian J. Bot. 9: 11-18.

Gomurgen, A.N., Potoglu-Erkara, I. and Altınozlu, H. 2010. Chromosome and pollen morphology of the rare endemic Centaurea lycopifolia Boiss. \& Kotschy. Bangladesh J. Bot. 39: 223-228.

Guner, A., Aslan, S., Ekim, T., Vural, M. and Babac, M.T. 2012. Türkiye bitkileri listesi (Damarlı bitkiler). Nezahat Gökyiğit Botanik Bahçesi ve Flora Araştırmaları Derneği Yayını: İstanbul. 
Hayta, S., Tasar, N., Kiran, Y., Cakılcıoglu, U. and Bagci, E. 2016. Morphological, karyological and palynological investigation of endemic Centaurea kurdica Reichardt from Turkey. Plant Biosyst. 150(3): 484-489.

Inceer, H., Hayırlıglu-Ayaz, S. and Ozcan, M. 2007. Chromosome numbers of the twenty-two Turkish plant species. Caryologia 60: 349-357.

Kaya, Z., Orcan, N. and Binzet, R. 2010. Morphological, anatomical and palynological study of Centaurea calcitrapa L. ssp. cilicica (Boiss. \& Bal.) Wagenitz and Centaurea solstitialis L. ssp. carneola (Boiss.) Wagenitz endemic for Turkey. Pakistan J. Bot. 42: 59-69.

Kocyigit, M. and Bona, M. 2013. Chromosome numbers of five Turkish Centaurea L. (Asteraceae) species. Plant Biosyst. 147: 970-978.

Kose, Y.B., Alan, S. and Yucel, E. 2010. Comparative investigation of the morphological characteristics of species belonging to the Centaurea L. section Phalolepis (Cass.) DC. Biol. Div. Conser. 3: 10-22.

Lersten, N.R. and Curtis, J.D. 1997. Anatomy and distribution of foliar idioblasts in Scrophularia and Verbascum (Scrophulariaceae). Am. J. Bot. 84: 1638-1645.

Levan, A., Fredga, K. and Sandberg, A.A. 1964. Nomenclature for centromeric position on chromosomes. Hereditas 52: 201-220.

Lu, H.F., Jiang, B., Shen, Z.G., Shen, J.B., Peng, Q.F. and Cheng, C.G. 2008. Comparative leaf anatomy, FTIR discrimination and biogeographical analysis of Camellia section Tuberculata (Theaceae) with a discussion of its taxonomic treatments. Plant Syst. Evol. 274: 223-235.

Makbul, S., Turkmen, Z., Coskuncelebi, K. and Beyazoglu, O. 2008. Anatomical and pollen characters in the genus Epilobium L. (Onagraceae) from Northeast Anatolia. Acta Bio. Crac. Ser. Bot. 50: 57-67.

Martin, E., Dinc, M., Duran, A. and Ozturk, M. 2006. Karyological studies on Lotus strictus Fisher and C.A. Mey. (Leguminosae), Centaurea amanicola Hub.-Mor. (Compositae) and Teucrium lamiifolium Durv. subsp. lamiifolium (Labiatae). Am-Eur. J. Sci. Res. 1: 12-17.

Martin, E., Dinc, M. and Duran, A. 2009. Karyomorphological study of eight Centaurea L. taxa (Asteraceae) from Turkey. Turk. J. Bot. 33: 97-104.

Meric, C., Arda, H., Guler, N. and Dayan, S. 2010. Chromosome number and nuclear DNA content of Centaurea kilaea (Asteraceae), an endemic species from Turkey. Phyt. Balcanica 16: 79-84.

Metcalfe, C.R. and Chalk, L. 1979. Anatomy of Dicotyledones I. Oxford University Press, Oxford, pp. 783803.

Negaresh, K. and Rahiminejad, M.R. 2014. A contribution to the taxonomy of Centaurea sect. Cynaroides (Asteraceae, Cardueae-Centaureinae) in Iran. Phytotaxa 158: 229-244.

Noman, A., Ali, Q., Hameed, M., Mehmood, T. and Iftikhar, T. 2014. Comparison of leaf anatomical characteristics of Hibiscus rosa-sinensis grown in Faisalabad Region. Pakistan J. Bot. 46: 199-206.

Ozcan, M. 2013. Türkiye'de yetişen Psephellus pulcherrimus (syn: Centaurea pulcherrima var. freynii) (Cardueae, Asteraceae)'un morfolojik ve anatomik özellikleri. Artvin Çoruh Univ. Orman Fak. Der. 14: 104-112.

Ozler, H., Kaya, Z. and Pehlivan, S. 2009. Pollen morphology of some Centaurea L., Psephellus Cass. and Cyanus Miller taxa. Acta Bio. Crac. Ser. Bot. 51: 53-66.

Paszko, B. 2006. A critical review and a new proposal of karyotype asymmetry indices. Plant Syst. Evol. 258: $39-48$.

Rahiminejad, M.R., Mozaffarian, V. and Montazerolghaem, S. 2010. A taxonomic revision of Centaurea section Acrocentron (Asteraceae) in Iran. Bot. J. Linn. Soc. 163: 99-106.

Ranjbar, M. and Negaresh, K. 2013. A revision of Centaurea sect. Phaeopappus (Asteraceae, Cardueae). Phytotaxa 123(1): 1-40.

Romero-Zarco, C. 1986. A new method for estimating karyotype asymmetry. Taxon 35: 526-530.

Stebbins, G.L. 1971. Chromosomal Evolution in Higher Plants. Edward Arnold. London, UK.

Türkoglu, I., Akan, H. and Civelek, E. 2003. A new species of Centaurea (Asteraceae: sect. Psephelloideae) from Turkey. Bot. J. Linn. Soc. 143: 207-212. 
Uysal, I., Celik, S. and Menemen, Y. 2005. Morphology, anatomy, ecology, pollen and achene features of Centaurea polyclada DC. (Sect. Acrolophus) in Turkey. J. Bio. Sci. 5: 176-180.

Uysal, T., Ertugrul, K., Susanna, A. and Garcia-Jacas, N. 2009. New chromosome counts in the genus Centaurea (Asteraceae) from Turkey. Bot. J. Linn. Soc. 159: 280-286.

Uysal, T., Hamzaoglu, E., Ertugrul, K. and Bozkurt, M. 2016. A new species of Centaurea (Asteraceae) from Turkey. Phytotaxa 275(2): 149-158.

Wagenitz, G. 1975. Centaurea L. In: Davis, P.H. (Ed.), Flora of Turkey and the East Aegean Islands. Vol. 5. Edinburgh University Press, UK.

Wagenitz, G. 1986. Centaurea in South-West Asia: Patterns of distribution and diversity. Edinburgh Proceedings of the Royal Society 89: 11-21.

Yakar-Tan, N. 1982. Bitki Mikroskopisi Klavuz Kitabı. İstanbul University, Faculty of Science Publishing, İstanbul, Turkey, $166 \mathrm{pp}$.

Yüzbaşıŏlu, İ.S., Bona, M. and Genç, İ. 2015. A new species of Centaurea sect. Pseudoseridia (Asteraceae) from north-eastern Turkey. PhytoKeys 53: 27-38.

(Manuscript received on 31 March 2018; revised on 21 October 2018) 